\title{
Quinoxalinylethylpyridylthioureas (QXPTs) as Potent Non-Nucleoside HIV-1 Reverse Transcriptase (RT) Inhibitors. Further SAR Studies and Identification of a Novel Orally Bioavailable Hydrazine-Based Antiviral Agent
}

\begin{abstract}
Giuseppe Campiani,*,§ Francesca Aiello," Monica Fabbrini," Elena Morelli," Anna Ramunno, ${ }^{\S}$ Silvia Armaroli," Vito Nacci," Antonio Garofalo, ${ }^{\perp}$ Giovanni Greco, ${ }^{\nabla}$ Ettore Novellino, $\nabla$ Giovanni Maga,‡ Silvio Spadari,, Alberto Bergamini, ${ }^{\dagger}$ Laura Ventura, ${ }^{\dagger}$ Barbara Bongiovanni, ${ }^{\dagger}$ Marcella Capozzi, ${ }^{\dagger}$ Francesca Bolacchi, ${ }^{\dagger}$ Stefano Marini,» Massimiliano Coletta,» Giovanna Guiso,\# and Silvio Caccia\#

Dipartimento di Scienze Farmaceutiche, Facolta' di Farmacia, Universita' degli Studi di Salerno, via Ponte Don Melillo 11C, 84084 Fisciano (Salerno), Italy, Dipartimento Farmaco Chimico Tecnologico, Universita' degli Studi di Siena, via Aldo Moro, 53100 Siena, Italy, Universita' della Calabria, 87036 Arcavacata, Cosenza, Italy, Dipartimento di Chimica Farmaceutica e Tossicologica, Universita' di Napoli "F ederico II", via D. Montesano 49, 80131 Napoli, Italy, Istituto di Genetica Biochimica ed Evoluzionistica (IGBE) - CNR, via Abbiategrasso 207, 27100 Pavia, I taly, Di partimento di Sanita' Pubblica e Biologia Cellulare (DSP\&BC), Universita' degli Studi di Roma “Tor Vergata”, via Tor Vergata 135, 00133 Roma, I taly, Dipartimento di Medicina Sperimentale e Scienze Biochimiche (DMS\&SB), Universita' degli Studi di Roma Tor Vergata, via Tor Vergata 135, 00133 Roma, I taly, and I stituto di Ricerche Farmacologiche "Mario Negri", via Eritrea 62, 20157 Milano, I taly
\end{abstract}

Received J uly 20, 2000

Quinoxal inylethylpyridylthioureas (QXPTs) represent a new class of human immunodeficiency virus type 1 (HIV-1) non-nucleoside reverse transcriptase (RT) inhibitors (NNRTIs) whose prototype is 6-FQXPT (6). Docking studies based on the three-dimensional structure of RT prompted the synthesis of novel heteroarylethylpyridylthioureas which were tested as antiHIV agents. Several compounds proved to be potent broad-spectrum enzyme inhibitors and significantly inhibited HIV-1 replication in vitro. Their potency depends on the substituents and the nature of the heterocyclic skeleton linked to the ethyl spacer, and structure-activity relationships are discussed in terms of the possible interaction with the RT binding site. Although the new QXPTs analogues show potent antiviral activity, none of the compounds tested overcome the pharmacokinetic disadvantages inherent to ethyl pyridylthioureidic antiviral agents, which in general have very low oral bioavailability. Through an integrated effort involving synthesis, docking studies, and biological and pharmacokinetic evaluation, we investigated the structural dependence of the poor bioavailability and rapid clearance within the thioureidic series of antivirals. Replacing the ethylthioureidic moiety with a hydrazine linker led to a new antiviral lead, offering promising pharmacological and pharmacokinetic properties in terms of antiviral activity and oral bioavailability.

\section{Introduction}

Among the antiviral agents so far proposed for the treatment of human immunodeficiency virus type 1 (HIV-1) infection, ${ }^{1}$ the non-nucleoside reverse transcriptase inhibitors (NNRTI) represent an intriguing class of therapeutic agents. Although NNRTIs are highly specific and less toxic than nucleoside inhibitors (Chart 1, zidovudine (AZT), 1), ${ }^{2}$ their therapeutic effectiveness is limited by relatively rapid emergence of drug-resistant HIV-1 strains and by the onset of skin rashes. NNRTIs (Chart 1) include structurally unrelated subclasses of compounds that bind a common al losteric

* To whom correspondence should be addressed. Tel: 0039-089964381. Fax: 0039-089-962828. E-mail: campiani@unisa.it.

§ Universita' degli Studi di Salerno.

" Universita' degli Studi di Siena.

$\perp$ Universita' della Calabria.

$\checkmark$ Universita' degli Studi di Napoli "Federico II".

‡ IGBE - CNR Pavia.

† DSP\&BC Universita' degli Studi di Roma "Tor Vergata".

- DMS\&SB Universita' degli Studi di Roma "Tor Vergata".

\# Istituto di Ricerche Farmacologiche "Mario Negri". site, adjacent to the NRTI (nucleoside reverse transcriptase inhibitor) binding site, by a similar threedimensional arrangement. HEPT and TIBO derivatives $(2)^{3}$ were the first compounds described in this class, followed by nevirapine $(3)^{4}$ and efavirenz (4), both of which have been approved for clinical use for the therapy of acquired immunodeficiency syndrome (AIDS). Recently the PETT class of RT inhibitors has been described. The representative compound of this series is trovirdine (5), a potent RT inhibitor that, however, has low oral bioavailability. ${ }^{5-7 a, b}$ In the course of our research aimed at identifying novel antiviral agents, ${ }^{8}$ we discovered that members of a series of quinoxalinylethylthioureas inhibited the replication of HIV-1 in different cell lines. ${ }^{9}$ First, we identified the tricyclic quinoxal ine system as a critical structural requirement for optimal interaction with the NNRTI binding site, and 6-FQXTP (6), a potent broad-spectrum secondgeneration NNRTI but characterized by unsatisfactory oral bioavailability, was selected as the lead compound. ${ }^{9}$ 


\section{Chart 1}<smiles></smiles>

1 zidovudine

(AZT)<smiles>Cc1ccnc2c1NC(=O)c1cccnc1N2C1CC1</smiles>

3 nevirapine

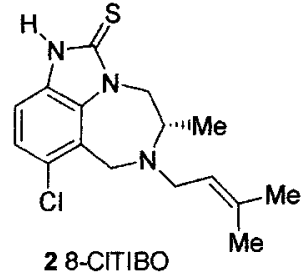<smiles>C[C@]1(C#CC2CC2)OC(=O)Nc2ccc(Cl)cc21</smiles>

4 efavirenz<smiles>S=C(NCCc1ccccn1)Nc1ccc(Br)cn1</smiles>

5 trovirdine (LY300046)

Chart 2. Planned Modifications to 6-FQXPT and the Newly Designed Antiviral Agents
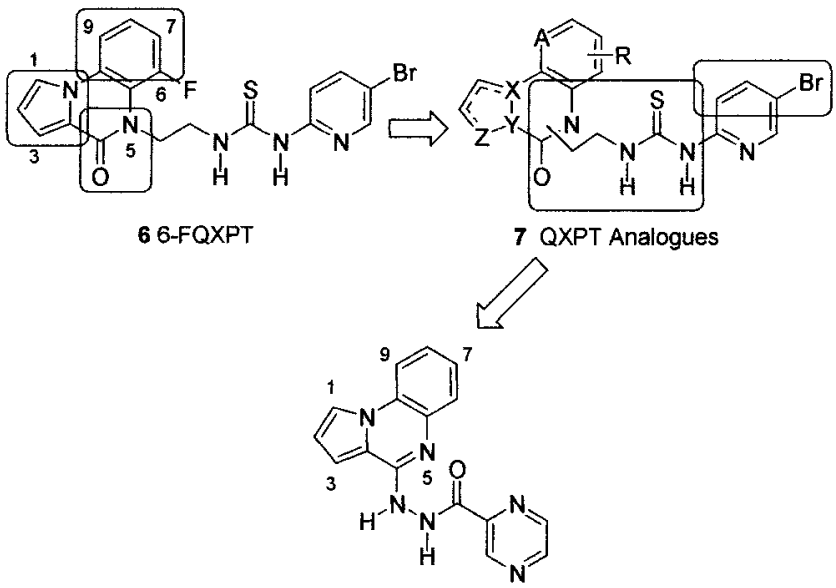

8 The New Antiviral Lead

To discover analogues with greater potency and better pharmacokinetic properties, we extended our structureactivity relationship (SAR) studies to assess the effect of a variety of substituents and heterocydic systems (7) in place of the quinoxalinyl scaffold of 6-FQXPT (Chart 2). Potent broad spectum RT inhibitors with high antiviral efficacy were identified (12 and 15). Despite these promising results, studies performed to evaluate the pharmacokinetic properties of the new compounds were disappointing. None of the tested compounds showed an improved pharmacokinetic profile over the known thioureidic antiviral agents in terms of oral bioavailability. Thus, starting from $\mathbf{6}$, the objective of the present study was also the development of QXPTrelated antiviral agents with better oral bioavailability to bypass the pharmacokinetic disadvantages inherent to the thioureas. Exploiting synthesis, molecular modeling, and biological evaluation, our SAR studies (Chart 2) led to the identification of the quinoxaline derivative $\mathbf{8}$, representative lead of a new class of RT inhibitors,

Scheme 1

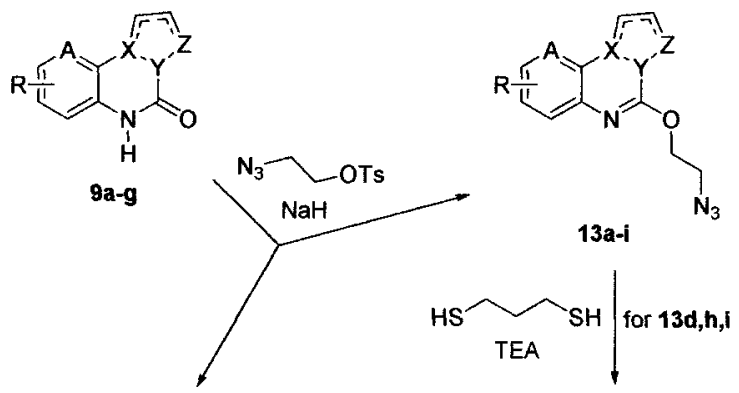

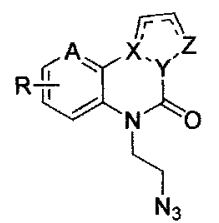

$10 a-g$<smiles>SCCCS</smiles>

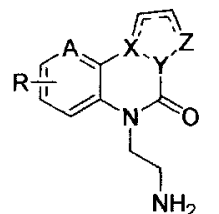

11a-g<smiles>Cc1ccc(Br)nc1N</smiles><smiles>[Y][X]c1ccccc1N(CCNC(=S)Nc1ccc(Br)cn1)C(=O)c1ccccc1</smiles>

12a-g<smiles></smiles>

$14 a-c$<smiles>S=[As]c1ccc(Br)cn1</smiles><smiles>COc1c2cccc-2n(C)c2c1ccn2I</smiles>

\begin{tabular}{|c|c|c|c|c|c|}
\hline & $\mathbf{R}$ & A & $x$ & $\mathbf{Y}$ & $\mathbf{z}$ \\
\hline $12 a$ & $7-\mathrm{F}$ & $\mathrm{CH}$ & $N$ & $c$ & $\mathrm{CH}$ \\
\hline $12 b$ & $9-\mathrm{F}$ & $\mathrm{CH}$ & $N$ & c & $\mathrm{CH}$ \\
\hline $12 c$ & 7,9-diF & $\mathrm{CH}$ & $\mathbf{N}$ & $\mathrm{C}$ & $\mathrm{CH}$ \\
\hline 12d & $7-\mathrm{Cl}$ & $\mathrm{CH}$ & $\mathrm{N}$ & $c$ & $\mathrm{CH}$ \\
\hline $12 e$ & $H$ & $N$ & $N$ & $c$ & $\mathrm{CH}$ \\
\hline $12 f$ & $H$ & $\mathrm{CH}$ & $N$ & C & $N$ \\
\hline $12 \mathrm{~g}$ & $\mathrm{H}$ & $\mathrm{CH}$ & $C$ & $N$ & $N$ \\
\hline $15 a$ & $6-F$ & & & & \\
\hline $15 b$ & $7-\mathrm{Cl}$ & & & & \\
\hline $15 \mathrm{c}$ & 7,8-diMe & & & & \\
\hline
\end{tabular}

offering satisfactory oral bioavailability and higher antiviral activity than that of nevirapine. Furthermore, this novel antiviral agent readly crosses the blood-brain barrier and has potent synergistic activity with AZT. Herein we report the synthesis and biological evaluation of a series of heterocyclic analogues of 6-F QXPT (12ag, 15a-c) and the development of 8. Pharmacokinetic and synergistic studies for the most active analogues were also done.

\section{Chemistry}

Syntheses were accomplished as schematized in Schemes 1 and 2 . The desired products $12 \mathbf{a}-\mathbf{g}$ and $\mathbf{1 5 a}-\mathbf{c}$ were prepared starting from the corresponding key amino intermediates $\mathbf{1 1 a}-\mathbf{g}$ and $\mathbf{1 4 a}-\mathbf{c}$ following a similar synthetic procedure using 2-(5-bromopyridyl)isothiocyanate, which is in turn prepared from 2-amino5-bromopyridine and 1,1'-thiocarbonyldiimidazole or thiophosgene. ${ }^{9}$ The azido intermediates $10 \mathbf{a}-\mathbf{g}$ and 
Scheme 2<smiles>O=c1[nH]c2ccccc2n2cccc12</smiles>

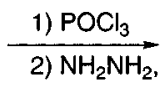

16

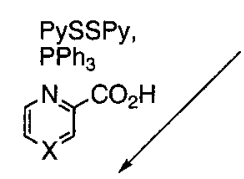<smiles></smiles>
$19 \times=\mathrm{CH}$

$\mathbf{1 3 a}-\mathbf{g}$ were obtained starting from the lactams $\mathbf{9 a}-\mathbf{g}$ by direct alkylation with tosylethyl azide, while $\mathbf{1 3 h}$ $(\mathrm{R}=6-\mathrm{F}, \mathrm{A}=\mathrm{CH}, \mathrm{X}=\mathrm{N}, \mathrm{Y}=\mathrm{C}$, and $\mathrm{Z}=\mathrm{CH}$ ) and $\mathbf{1 3 i}$ $(\mathrm{R}=7,8$-diMe, $\mathrm{A}=\mathrm{CH}, \mathrm{X}=\mathrm{N}, \mathrm{Y}=\mathrm{C}$, and $\mathrm{Z}=\mathrm{CH}$ ) were previously synthesized. ${ }^{9}$ The lactams $\mathbf{9 a} \mathbf{- g}$ were prepared according to previously described procedures. ${ }^{10-14}$ Usually the O-alkylated products were obtained in $10-25 \%$ yield. After examination of several reduction methods, we found that treatment of azides 10a-g and 13d,h,i with 1,3-propanedithiol-triethylamine in methanol ${ }^{15}$ provided the corresponding amines $\mathbf{1 1 a}-\mathbf{g}$ and $\mathbf{1 4 a}-\mathbf{c}$. Last, by treatment of $\mathbf{1 1} \mathbf{a}-\mathbf{g}$ and 14a-c with 2-(5-bromopyridyl)isothiocyanate in the presence of triethylamine we obtained the thioureas $\mathbf{1 2} \mathbf{a}-\mathbf{g}$ and $\mathbf{1 5} \mathbf{a}-\mathbf{c}$. The syntheses of compounds $\mathbf{8}$ and $\mathbf{1 8 a}, \mathbf{b}$ are outlined in Scheme 2. Lactam $16^{10}$ was transformed to the hydrazine derivatives $\mathbf{1 7}$ by means of phosphorus oxychloride and hydrazine. Treatment of 17 with triphosgene and 2-amino-5-bromopyridine provided 18a, while treatment of $\mathbf{1 7}$ with 5-bromopyridyl2-isothiocyanate (in turn obtained from 2-amino-5bromopyridine and 1,1'-thiocarbonyldiimidazole) furnished 18b. Moreover, reaction of $\mathbf{1 7}$ with pyrazinecarboxylic acid or pyridine-2-carboxylic acid, in the presence of triphenylphosphine and Aldrithiol-2,16 gave $\mathbf{8}$ and 19, respectively, in good overall yield.

\section{Biological Results}

Enzymatic Assays. In Vitro SAR Studies. The newly described ethylpyridylthioureas $\mathbf{1 2 a}-\mathbf{g}$ and $\mathbf{1 5 a}-$ c, and the analogue 8, were tested in an in vitro HIV-1 RTwt assay to evaluate their potential as anti-HIV drugs. The results are summarized in Table 1 as $\mathrm{K}_{i}$ values. In addition, in order to evaluate the potential of these antienzymatic derivatives as novel broadspectrum antiviral agents, the whole set of active compounds was also tested on a panel of RT mutants including L100I , Y181I, V106A, one of the most commonly identified mutations associated with dipyridodiazepinones, and $\mathrm{K} 103 \mathrm{~N}$, a mutant associated with resistance to pyridones and nevirapine as well. The
Table 1. Inhibition of HIV-1 Wild-Type RT and HIV-1 Mutant HIV-1 RT Enzymes Containing the Single Amino Acid Substitutions L100I, V179D (for 15b,c), K103N, V106A, Y181I, and $Y 188 L$ by Compounds 8, 12a-g, 15a-c, and 18a,b, and 19

\begin{tabular}{|c|c|c|c|c|c|c|c|}
\hline \multirow[b]{2}{*}{ compd } & \multicolumn{7}{|c|}{$\begin{array}{l}\text { HIV-1 RT K } \mathrm{K}_{\mathrm{i}}(\mu \mathrm{M})^{\mathrm{a}} \\
\text { poly rA }(\mathrm{dT})_{12-18}\end{array}$} \\
\hline & WT & L100I & V179D & K $103 N$ & V106A & Y181I & Y 188L \\
\hline 8 & 0.19 & 0.3 & & NA & 0.8 & 2.5 & 1.8 \\
\hline $12 a$ & 0.029 & 0.7 & & 0.65 & 0.04 & 1.0 & 1.2 \\
\hline $12 b$ & 0.04 & 0.8 & & 0.4 & 0.06 & 0.9 & 0.2 \\
\hline $12 c$ & 0.022 & 0.1 & & NA & 0.03 & 1.6 & 0.45 \\
\hline 12d & 0.02 & 0.16 & & 0.15 & 0.02 & 0.24 & 0.9 \\
\hline $12 e$ & 0.009 & 0.095 & & 0.25 & 0.05 & 0.4 & 0.13 \\
\hline $12 f$ & 0.25 & 1.0 & & 0.24 & 0.35 & 1.4 & 5.0 \\
\hline $12 \mathrm{~g}$ & 0.015 & 0.1 & & 0.021 & 0.33 & 0.52 & 0.4 \\
\hline $15 a$ & 0.058 & 0.15 & & 0.35 & 0.029 & 0.3 & 0.7 \\
\hline 15b & 0.053 & 0.12 & 0.07 & 0.21 & 0.12 & 0.09 & 0.1 \\
\hline $15 c$ & 0.22 & 0.5 & 0.8 & 0.45 & 0.15 & 0.66 & 1.5 \\
\hline 18a & 2.6 & & & & & & \\
\hline $18 b$ & 1.9 & & & & & & \\
\hline 19 & 4.0 & & & & & & \\
\hline QXPT $\mathrm{b}$ & 0.058 & 0.105 & & 0.1 & 0.112 & 4.0 & 2.5 \\
\hline 6-FQXPT'b & 0.009 & 0.17 & & 0.16 & 0.015 & 0.2 & 0.2 \\
\hline efavirenz & 0.03 & 0.12 & & 0.16 & 0.04 & 0.15 & 0.3 \\
\hline nevirapine & 0.4 & 9 & & 7 & 10 & 36 & 18 \\
\hline
\end{tabular}

a Inhibition of HIV-1 RT activities. All data listed were compared to the corresponding test results for nevirapine, performed at the same time.The $\mathrm{K}_{\mathrm{i}}$ is stated as the mean of at least three experiments. ${ }^{b}$ From ref 9 . $\mathrm{NA}=$ not active.

Y 188L, a mutation of RT that appears in patients treated with both nevirapine and AZT, was also included.

The first question addressed was whether, by expanding the SAR studies of the QXPT class of antiviral agents, the antiviral activity, the broadening of the spectrum of antienzymatic activity, and, possibly, the pharmacokinetic properties could be improved over the known thioureas. SAR studies were conducted by appropriately varying the substituents on the benzo-fused ring and by introducing different heteroaryl systems in place of the pyrroloquinoxaline of the lead 6 (6-F QXPT).

As illustrated in Table 1 for compounds $\mathbf{1 2} \mathbf{a}-\mathbf{g}$ and $\mathbf{1 5} \mathbf{a}-\mathbf{c}$, the potency of inhibition of RTwt and mutated RTs is strictly dependent on the nature of the substituents on the aromatic system. By comparing the inhibitory activity $\left(\mathrm{K}_{i} \mathrm{~S}\right)$ of compounds $\mathbf{1 2} \mathbf{a}-\mathbf{c}$ to that of 6-FQXPT (6), it clearly appears that the electronwithdrawing fluorine is preferred at C-6 (6-F QXPT), this being 4-fold more potent against RT wt than its 7-, 9-, and 7,9-fluorinated analogues $(\mathbf{1 2 a}-\mathbf{c})$. While against the V106A mutant 12a-c show a comparable activity to that of 6-FQXPT (6), the 7,9-difluoro analogue 12c proved to be inactive against the K103N mutant, maintaining significant potency vs Y 188L mutant. The analogue 12d (7-CIQXPT) is slightly less potent than 6 (6-F QXPT) vs RT wt, but it is about 4-fold more active than 12a (7-F QXPT) against L 100I , V106A, K 103N, and Y 181I. In general, the halogenated analogues show greatly improved antienzymatic properties over their unsubstituted counterpart QXPT. ${ }^{9} \mathrm{~F}$ urthermore, within this series, the antienzymatic potency and the broadening of spectrum of activity are also influenced by the nature of the heterocyclic skeleton (12e-g vs 6-F QXPT).

By comparing the $\mathrm{K}_{i} \mathrm{~S}$ (Table 1 ) of unsubstituted QXPT and 6-F QXPT for inhibition of RTwt, L 100I , K103N, and V106A with those of $\mathbf{1 2 f}$ (I MQXPT), the key role played by the pyrrole ring with respect to the imidazole 
(unsubstituted QXPT ${ }^{9}$ vs $\mathbf{1 2 f}$ ) is evident. On the contrary, the pyrazole ring in place of the pyrrole (12g vs unsubstituted QXPT ${ }^{9}$ ) greatly improves the inhibitory activity against $Y 181 \mathrm{l}$ and $\mathrm{Y} 188 \mathrm{~L}$ mutants $\left(\mathbf{1 2 g}, \mathrm{K}_{i}=\right.$ 0.52 and $0.40 \mu \mathrm{M}$, respectively). We also investigated the analogue 12e (PyrPZPT) in which the benzo-fused ring of $\mathbf{6}$ is replaced by a pyridine system. In this case 12e shows increased anti-Y 181I/Y 188L activity, maintaining high potency against RTwt. Taking into account the inhibitory potency against RTwt and the other mutants, especially vs Y188L, it appears that $\mathbf{1 2}$ e (PyrPZPT) represents one of the most potent secondgeneration RT inhibitors.

The O-alkylated regioisomers $\mathbf{1 5 a}-\mathbf{c}$ were further investigated and included in Table 1 . Compounds 15a and $\mathbf{1 5 b}$ proved to be potent broad-spectrum RT inhibitors, being as active as their $\mathrm{N}$-al kylated isomers ( 6 and 12d). In particular, 15b demostrated higher potency vs Y181l and Y188L than its N-alkylated isomer 12d.

When subjected to preliminary pharmacokinetic studies, the most representative thioureas proved to be not bioavailable after oral administration, probably by rapid metabolic inactivation and clearance (first-pass hepatic el imination) (see Preliminary Pharmacokinetic Studies section). Since this unfavorable behavior was shown by thioureas characterized by different heteroaryl systems, the subsequent question addressed was whether through an alteration of the linker between the heteroaryl and the 5-bromopyridine groups an antiviral agent with higher hydrophilicity and, of consequence, higher oral bioavailability, maintaining the 3D pharmacophoric arrangement for an optimal interaction with the NNRTI binding site, could be devel oped. Starting from QXPTs, by replacing the ethylthiourea moiety with a semicarbazide or a thiosemicarbazide group, two inactive compounds were obtained $(\mathbf{1 8 a}, \mathbf{b})$. F urthermore, shortening the linker with hydrazine, and maintaining the distal pyridine ring, compound $\mathbf{1 9}$ was obtained, characterized by a low antienzymatic activity. Conversely, replacing the pyridinoyl with a pyrazinoyl group, we identified the new reverse transcriptase inhibitor $\mathbf{8}$. As shown in Table 1, although less potent than thioureas (8 vs unsubstituted QXPT ${ }^{9}$ and 6), compound 8 displays antienzymatic activity against RT wt and mutants higher than that of nevirapine, and it represents a great improvement in oral bioavailability over known ethylthioureas (see Preliminary Pharmacokinetic Studies section). Replacement of the pyrazine nucleus of $\mathbf{8}$ with pyridine (19) and substituted pyridines (data not shown), leading to inactive compounds, demostrated the critical role played by the distal nitrogen of the pyrazine ring.

Computational studies were performed to develop docking models of 8 and 15a into the HIV-1 NNRTI binding site which could guide further lead optimization efforts. The coordinates of the RT/nevirapine complex solved by Ren et al. ${ }^{17}$ were employed to model the target protein. All calculations were performed using molecular mechanics (Tripos force fiel $d^{18}$ ), conformational analysis, docking, and graphics routines available within the SYBYL program. ${ }^{19}$ Details of these procedures are described in the Experimental Section, whereas results are summarized bel ow.

According to our model of RT/8 complex (see Figure 1 ), the pyrazine $\mathrm{N} 4$ atom receives a hydrogen bond from

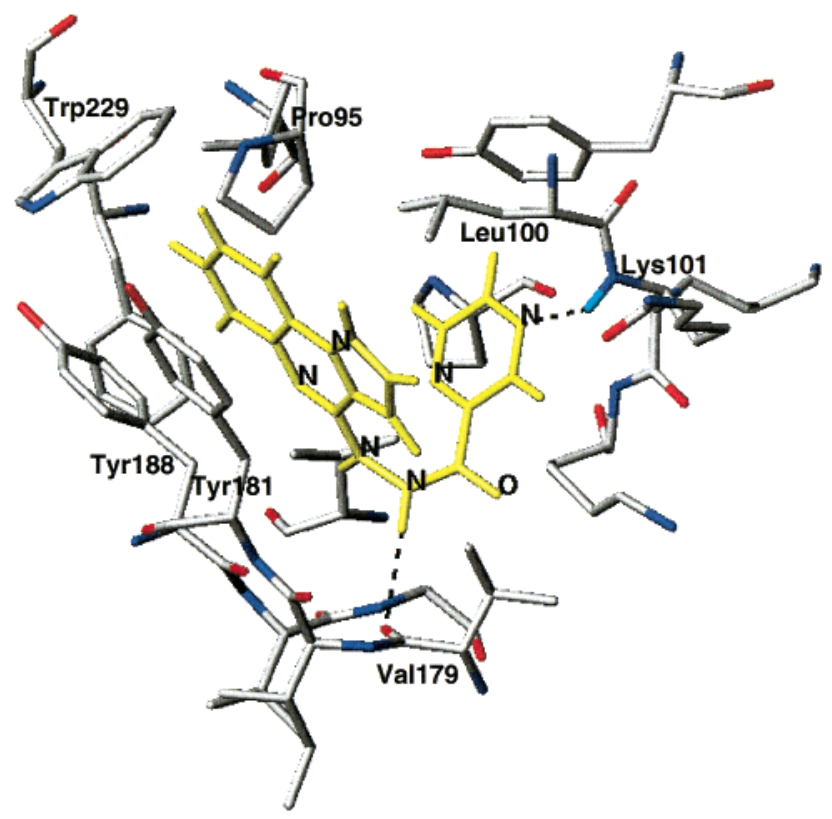

Figure 1. Model of the RT/8 complex. Dotted lines highlight intramolecular hydrogen bonds. To improve clarity, only residues within $4 \AA$ from the inhibitor are displayed and Glu138 and Pro236 have been excluded.

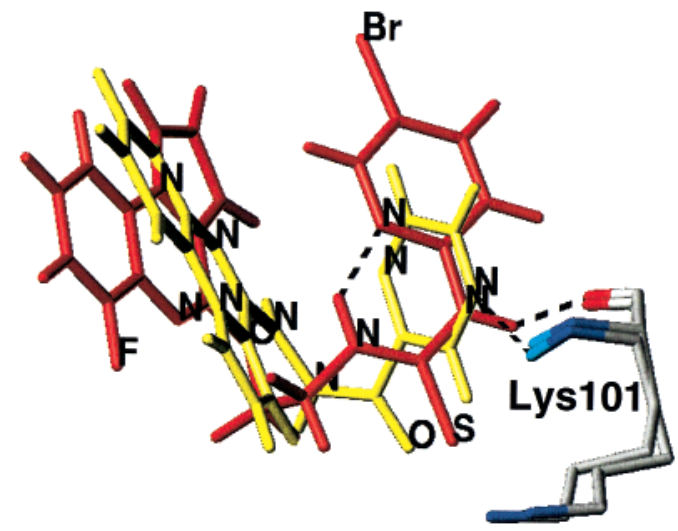

Figure 2. Overlay of the putative RT-bound conformations of $\mathbf{8}$ (yellow) and 15a (red) extracted together with Lys101 from the RT/8 and RT/15a complexes.

the backbone NH group of Lys101. This interaction rationalizes the loss of inhibitory activity resulting from replacement of the pyrazine $\mathrm{N} 4$ with a $\mathrm{CH}$ fragment to yield the pyridine derivative (19). An additional intermolecular hydrogen bond is hypothesized to occur between the hydrazide CONH and the Val 179 carbonyl oxygen. The pyrrol oquinoxal ine and pyrazine rings are arranged in a butterfly-like arrangement adopted by most NNRTIs. ${ }^{20}$ The tricyclic system is hosted in cavity made up by the aromatic side chains of Tyr181, Tyr188, and Trp229.

Figure 2 shows a superposition of the putative RTbound geometries of $\mathbf{8}$ and $\mathbf{1 5} \mathbf{a}^{\mathbf{7 b}}$ extracted together with Lys101 from the corresponding complexes. The pyrroloquinoxaline systems dock similarly although they are not coincident atom by atom. None of the pyrazine nitrogens of $\mathbf{8}$ match the pyridine nitrogen of 15a. Each of the thioureidic $\mathrm{NH}$ groups of 15a makes a hydrogen bond: one with the pyridine nitrogen (intramolecular) and the other one with the Lys101 carbonyl oxygen 
Table 2. Inhibition of HIV-1 Infection in CEM-SS Cells, ${ }^{a}$ Inhibition of HIV-IIIB Infection in C8166 Cells, and Cytotoxicity on NSO Murine Cell Line, Daudi Human (DH) Cell Line, 3T3 Fibroblasts (3T3F) Murine Cell Line, and Normal Human Lymphocytes (HL)

\begin{tabular}{|c|c|c|c|c|c|c|c|c|c|c|}
\hline \multirow[b]{2}{*}{ compd } & \multicolumn{3}{|c|}{ CEM-SS cells } & \multicolumn{3}{|c|}{ C8166 cells } & \multicolumn{4}{|c|}{$\mathrm{TC}_{50}(\mathrm{mM})$} \\
\hline & $\mathrm{IC}_{50} \mathrm{~b}(\mu \mathrm{M})$ & $\mathrm{EC}_{50}{ }^{\mathrm{c}}(\mu \mathrm{M})$ & $\mathrm{SI}^{\mathrm{d}}$ & $\mathrm{IC}_{50} \mathrm{~b}(u \mathrm{M})$ & $\mathrm{EC}_{50}{ }^{\mathrm{c}}(\mu \mathrm{M})$ & $\mathrm{SI}^{\mathrm{d}}$ & $\mathrm{NSO}^{\mathrm{e}}$ & $\mathrm{DH}^{\mathrm{e}}$ & $3 \mathrm{~T} 3 \mathrm{~F}^{\mathrm{e}}$ & $\mathrm{HL}^{\mathrm{e}}$ \\
\hline $12 a$ & $>200$ & 0.063 & $>3170$ & 15 & 0.032 & 468 & 0.02 & 0.019 & 0.02 & 0.02 \\
\hline $12 b$ & $>2$ & 0.0019 & $>110$ & 21 & 0.2 & 105 & 0.52 & 0.51 & 0.5 & 0.51 \\
\hline $12 c$ & $>2$ & 0.085 & $>23$ & & & & NT & NT & NT & NT \\
\hline $12 d$ & $>2$ & 0.0018 & $>1080$ & 7 & 0.061 & 123 & 0.97 & 0.96 & 0.98 & 0.97 \\
\hline $12 e$ & $>2$ & 0.0052 & $>380$ & 11 & 0.124 & 89 & 0.7 & 0.69 & 0.69 & 0.68 \\
\hline $12 f$ & $>2$ & 0.013 & $>150$ & 88 & 0.32 & 275 & 0.68 & 0.68 & 0.69 & 0.67 \\
\hline $15 a$ & $>2$ & 0.0029 & $>690$ & 125 & 0.020 & 6250 & $>1$ & $>1$ & $>1$ & $>1$ \\
\hline $15 b$ & & & & 93 & 0.025 & 3720 & $>1$ & $>1$ & $>1$ & $>1$ \\
\hline 8 & & & & 18 & 0.4 & 40 & 0.87 & 0.86 & 0.88 & 0.87 \\
\hline QXPT ${ }^{f}$ & & & & 17 & 0.38 & 45 & 0.8 & 0.8 & 0.8 & 0.8 \\
\hline 6-FQXPT ${ }^{f}$ & $>0.02$ & 0.00047 & $>43$ & 200 & 0.025 & 7990 & 1.0 & 1.0 & 1.0 & 0.96 \\
\hline 8-CITIBO & & & & 50 & 0.030 & 1670 & & & & \\
\hline AZT & $>1$ & 0.0019 & 526 & $>100$ & 0.4 & $>250$ & & & & \\
\hline
\end{tabular}

a Testing was performed by the National Cancer Institute's Developmental Therapeutics Program, AIDS antiviral screening program. All the data listed were compared to the corresponding test results for AZT which served as the treated control, performed at the same time. ${ }^{b}$ The $I C_{50}$ value is the test compound concentration which results in a $50 \%$ survival of uninfected untreated control CEM-SS and C8166 cells (e.g., cytotoxicity of the test drug). ' ${ }^{c}$ The $\mathrm{EC}_{50}$ value is the test compound concentration which produces a $50 \%$ survival of $\mathrm{HIV}$

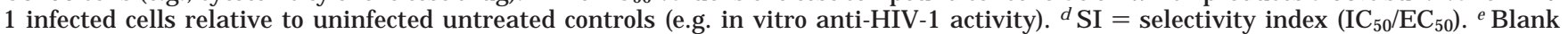
was subtracted from O.D. measured at $570 \mathrm{~nm}$. All data reported in table are measured O.D. $\times 1000$. Standard deviations are not reported in the table but never exceded $5 \%$ of the mean value. O.D.s measured in the control row were as follows: NSO $0.125 \pm 0.015$; DH $0.129 \pm 0.018 ; 3 T 3 F 0.131 \pm 0.014 ; \mathrm{HL} 0.114 \pm 0.01 .{ }^{f}$ From ref 9.

(intermolecular). Differences in the binding modes of $\mathbf{8}$ and $\mathbf{1 5 a}$ imply different lead optimization strategies in the hydrazide- and thiourea-based series.

Secondary Tests. A selected set of active compounds in enzymatic assays was evaluated for its ability to inhibit the HIV-1 wt cytopathicity on T4 cells (CEMSS), to inhibit syncytia formation on C8166 cells infected with wild-type HIV-1 $1_{\text {III }}$ virus. F urthermore, compounds $\mathbf{1 2 a}$ and $\mathbf{8}$, representative of the two series of antienzymatic agents, were further tested on monocytemacrophages infected with HTLV-III Ba-L (a laboratory adapted monocytotropic strain) in order to confirm their potential as antiviral agents. MTT assays were also conducted as a measure of the cytotoxic effect of the new compounds on four different cell lines, and synergistic antiviral activity with AZT has been calculated for representative antiviral agents.

Cell Culture Assays and MTT Assays. The results are presented in Table 2. For compounds bearing the quinoxaline system $(\mathbf{1 2} \mathbf{a}-\mathbf{d})$, potent antiviral activity in CEM-SS and C8166 cells was found, comparable to that of $\mathbf{6}$, although $\mathbf{1 2 b}$, in C8166 cells, proved to be less active than the counterparts $\mathbf{1 2 a}$ and $\mathbf{1 2 d}$. Replacement of the benzo-fused ring with a pyridine led to an analogue with great antiviral efficacy (12e vs QXPT), while replacement of the pyrrole ring of unsubstituted QXPT with an imidazole (12f) maintained antiviral activity (C8166 cells). The O-alkylated regioisomers of $12(\mathbf{1 5 a}, \mathbf{b})$ were also tested on CEM-SS and C8166 cells. By comparing the data for 6 and 15a in Table 2 (CEMSS and C8166), an apparent discrepancy arose. In fact, 15a shows low antiviral efficacy on C8166 cells while its $\mathrm{EC}_{50}$ on CEM-SS cells is equal to $2 \mathrm{nM}$. In C8166 cells, the new hydrazine derivative $\mathbf{8}$ showed a lower antiviral efficacy with respect to those of QXPTs and related compounds, although it was comparable to that of AZT tested in the same experimental conditions. Furthermore, two representative derivatives (8 and 12a) were also studied on monocyte-macrophages infected by HTLV-III Ba-L (Table 3). HIV-1 infection of monocytemacrophages is an important event in the pathogenesis of AIDS. Monocyte-macrophages differ from $\mathrm{T}$ cells for
Table 3. Inhibition of HIV-1-p24 Antigen Production in Monocyte-Macrophagesa by Compounds 8 and $\mathbf{1 2 a}$

\begin{tabular}{lccr}
\hline \multicolumn{1}{c}{ compd } & $\mathrm{IC}_{50}(\mu \mathrm{M})^{\mathrm{b}}$ & $\mathrm{EC}_{50}(\mu \mathrm{M})^{\mathrm{c}}$ & \multicolumn{1}{c}{$\mathrm{SI}^{\mathrm{d}}$} \\
\hline $\mathbf{8}$ & 25 & 0.2 & 125 \\
12a (7-FQXPT) & 49 & 0.004 & 12200 \\
6-FQXPTe & 17 & 0.002 & 8800 \\
\hline
\end{tabular}

a Antiviral activity was determined after 14 days after infection. For comparison, HIV-1-p24 antigen production in control cells was $22.789 \mathrm{pg} / \mathrm{mL}$. All the data listed were compared to the corresponding test results for AZT which served as the treated control, performed at the same time. ${ }^{\mathrm{b}}$ The $\mathrm{IC}_{50}$ value is the test compound concentration which results in a $50 \%$ survival of uninfected untreated control macrophages cells (e.g., cytotoxicity of the test drug). ${ }^{\mathrm{C}}$ The $\mathrm{EC}_{50}$ value is the test drug concentration which produces a $50 \%$ reduction of HIV-1-p24 antigen production in infected cells relative to uninfected untreated controls (e.g., in vitro anti-HIV-1 activity). ${ }^{d} \mathrm{SI}=$ selectivity index $\left(\mathrm{IC}_{50} / \mathrm{EC}_{50}\right)$. ${ }^{\mathrm{e}}$ From ref 9.

a number of aspects which could possibly affect the antiHIV activity of some antiviral agents. In our case, 12a proved to be extremely potent in this test, while $\mathbf{8}$ confirmed its significant efficacy, in the submicromolar range. Taking into account the data shown in assays using different infected cells, 12a-e,g appear to be among the most potent second-generation anti-HIV agents, while the quinoxal ine derivative $\mathbf{8}$, although less potent than QXPTs, is a representative lead of a new class of antiviral agents.

The low cytotoxicity was also confirmed by screening compounds in a MTT assay (3-(4,5-dimethylthiazol-2yl)2,5-diphenyltetrazolium bromi de) by using NSO murine, Daudi human, 3T3 fibroblast murine cell lines, and normal human limphocytes (Table 2). Most of the tested compounds show weak cytotoxicity.

Synergistic Antiviral Activity with AZT (and DDI). Resistance is a major concern in the chemotherapy of AIDS, and the recent therapeutic strategies converge to favor multidrug regimens which are more safe and effective against the HIV-1 infection, with simultaneous reduction on drug dosages, toxicity, and resistance. A further improvement in multidrug therapy would be to administer combinations of drugs able to interact synergistically. One of the clinically preferred 
Table 4. $\mathrm{EC}_{50}$ and Combination Index for Different Anti-HIV-1 Compounds in Association with AZT (and DDI for 8), Calculated Using Both the Mutually Nonexclusive and the Mutually Exclusive Assumptiona

\begin{tabular}{|c|c|c|c|c|c|}
\hline \multirow[b]{2}{*}{ compound } & \multicolumn{3}{|c|}{$\mathrm{EC}_{50}(\mathrm{nM})$} & \multicolumn{2}{|c|}{$\mathrm{Cl}^{\mathrm{b}}$} \\
\hline & $\begin{array}{l}\text { of compound } \\
\text { alone }\end{array}$ & $\begin{array}{c}\text { of compound } \\
\text { with AZT (DDI)c }\end{array}$ & $\begin{array}{l}\text { of AZT }(D D I)^{c} \\
\text { with compound }\end{array}$ & $\begin{array}{l}\text { mutually exclusive } \\
\text { assumption }\end{array}$ & $\begin{array}{l}\text { mutually nonexclusive } \\
\text { assumption }\end{array}$ \\
\hline none & & & 400 (1300) & & \\
\hline & 450 & 15 (140) & $98(0.84)$ & 0.640 (1.18) & $0.570(0.97)$ \\
\hline 12a (7-F QXPT) & 66 & 57 & 85 & 0.700 & 0.600 \\
\hline 12 e (PyrPZPT) & 124 & 50 & 15 & 0.470 & 0.450 \\
\hline $12 f$ (I mQXPT) & 588 & 460 & 66 & 1.070 & 0.940 \\
\hline 6-FQXPTd & 25 & 2 & 3 & 0.091 & 0.090 \\
\hline
\end{tabular}

${ }^{a}$ C8166 cells were infected with $\mathrm{HIV}-\mathrm{IIIB} .{ }^{\mathrm{b}} \mathrm{Cl}>1, \mathrm{Cl}=1$, and $\mathrm{Cl}<1$ indicate antagonistic, additive, and synergistic activities, respectively. The $\mathrm{Cl}$ values were calculated at $50 \%$ antiviral activity using both the mutually nonexclusive and the mutually exclusive form of the equation. ${ }^{\mathrm{c}} \mathrm{EC}_{50}$ and the combination index for $\mathbf{8}$ in association with DDI are shown in brackets. ${ }^{\mathrm{d}}$ From ref 9.

combinations among those drugs acts on different receptor sites within the same viral protein. ${ }^{21}$ Accordingly, to evaluate the potential of the new series of inhibitors in a multidrug approach, we investigated the synergistic antiviral activity of $\mathbf{8}, \mathbf{1 2 a}, \mathbf{1 2} \mathbf{e}$, and $\mathbf{1 2 f}$ in combination with the nucleoside analogue AZT (and DDI for 8) (Table 4). The compounds tested proved to be able to potentiate the antiviral activity of AZT, and AZT was able to potentiate their activity. The extent of the synergistic activity was quantified according to Chou and Talalay by the calculation of the combination index (CI). Compounds 12a,e showed a synergistic anti-HIV-1 activity $(\mathrm{Cl}<1)$ when tested in combination with AZT, notwithstanding the mutually exclusive or nonexclusive assumption formulas that were used (Table 4). On the contrary, 12f showed an additive antiviral activity $(\mathrm{Cl}=1)$. It is noteworthy that the new antiviral agent 8 showed a strong synergistic anti-HIV-1 activity in combination with AZT. Synergistic activity was less evident when 8 was tested in combination with DDI. Data shown in Table 4 confirm these new reverse transcriptase inhibitors to be potentially useful in combination therapies.

Preliminary Pharmacokinetic Studies. ${ }^{22-26 a, b}$ In previous studies we showed that the ethylpyridylthioureidic derivative 6 (6-FQXPT) ${ }^{9}$ rapidly reaches the systemic circulation and enters the brain after subcutaneous dosing in mice. However, its plasma and brain concentrations were low and variable and rapidly fell bel ow the limit of quantitation, possibly because of rapid and extensive biotransformation. Findings were similar with its 9-fluoro-substituted analogue $\mathbf{1 2 b}$ (data not shown). After oral dosing ( $20 \mathrm{mg} / \mathrm{kg}$ ), compounds 6 and 12b were undetectable in mouse plasma within the limits of sensitivity of the analytical procedure (about $0.1 \mathrm{nmol} / \mathrm{ml}$, using $0.2 \mathrm{~mL}$ of plasma).

In the same experimental conditions ( $20 \mathrm{mg} / \mathrm{kg}$ orally, suspended in PEG400:Tween 80, 80:20, v/v) the 7,9difluoro-substituted analogue 12c showed low oral bioavailability too. The same was achieved with the more lipophilic O-alkylated regioisomer 15a (i.e., plasma concentrations were less than $0.1 \mathrm{nmol} / \mathrm{mL}$ within $2 \mathrm{~h}$ of oral dosing). Possibly the water insolubility and high lipophilicity of these ethyl pyridylthioureidic derivatives prevent their efficient absorption and/or lead to extensive presystemic biotransformation.

Synthetic and pharmacokinetic efforts were then focused on the development and characterization of novel NNRTIs: by modifications of the structure of QXPTs, the new lead 8 was identified (see Table 1). This

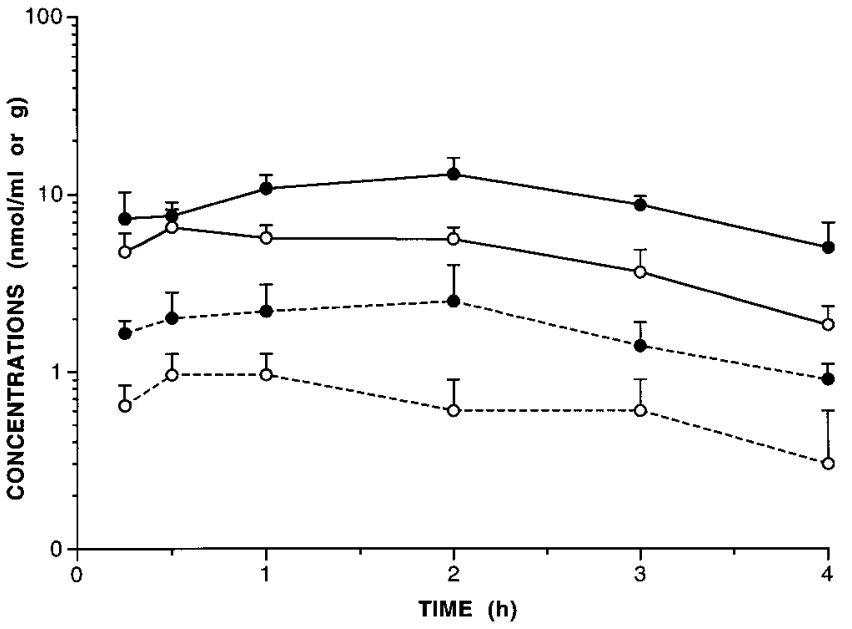

Figure 3. Plasma and brain concentration-time curves of compound $\mathbf{8}$ after subcutaneous and oral administration in mice. Each point represents the mean plasma (solid line) and brain concentrations $(n=3)$ of subcutaneously (closed circles) and orally (open circles) administered $\mathbf{8}$.

hydrazide derivative was expected to possess a higher solubility and a lower lipophilicity compared with the thioureidic analogues of type $\mathbf{1 2}$ and $\mathbf{1 5}$ as suggested by the following calculated n-octanol/water logP values of $\mathbf{8}, \mathbf{1 2 c}$, and 15a: $1.1,3.7$, and 4.9, respectively. ${ }^{26 \mathrm{~b}}$ Figure 3 shows the plasma concentration-time curves of compound $\mathbf{8}$ after subcutaneous and oral dosing in mice. Subcutaneous absorption was relatively slow, as indicated by the plasma $t_{\max }$ which averaged $120 \mathrm{~min}$ after a $20 \mathrm{mg} / \mathrm{kg}$ dose. The mean $\mathrm{C}_{\max }$ was $12.9 \pm 3.1$ $\mathrm{nmol} / \mathrm{ml}(\mathrm{n}=3)$. Under the assumption of complete absorption of $\mathbf{8}$ from the subcutaneous injection site into the systemic circulation, the mean total body $\mathrm{Cl}$ averaged $22.5 \mathrm{~mL} / \mathrm{min} / \mathrm{kg}$. In conjunction with a relatively high $\mathrm{Vd}$ of $3 \mathrm{~L} / \mathrm{kg}$, this resulted in a mean elimination $t_{1 / 2}$ of $1.5 \mathrm{~h}$, although this could only be calculated with limited accuracy because of the short sampling interval.

Absorption of $\mathbf{8}$ was faster after oral dosing, with a mean plasma $C_{\max }(6.5 \pm 1.7 \mathrm{nmol} / \mathrm{ml})$ at $30 \mathrm{~min}$. Mean plasma concentrations of the compound declined from the peak with elimination $t_{1 / 2}$ of $1.4 \mathrm{~h}$, similar to that after subcutaneous injection. The relative bi oavailability, calculated from the AUC of the compound after an oral $(21.7 \mathrm{nmol} / \mathrm{ml} / \mathrm{h})$ and subcutaneous $(48.7 \mathrm{nmol} / \mathrm{ml} /$ h) dose of $20 \mathrm{mg} / \mathrm{kg}$, was about $45 \%$.

Since the brain is a site of infection and viral replication for HIV-1, effective brain entry is a desirable property of new NNRTIs. It was therefore of interest preliminarily to examine the passage of $\mathbf{8}$ across the 
blood-brain barrier and the relationship between brain and plasma concentrations. Reflecting the time profiles in the systemic circulation, 8 achieved mean brain $\mathrm{C}_{\max }$ at approximately the same time as in plasma after either subcutaneous $(3.0 \pm 1.4 \mathrm{nmol} / \mathrm{g}$, at $120 \mathrm{~min})$ or oral dosing $(0.9 \pm 0.1 \mathrm{nmol} / \mathrm{g}$, at $30 \mathrm{~min})$. After the peak, mean brain concentrations disappeared al most in parallel with plasma concentrations, with similar el imi nation $t_{1 / 2}$ looking at the whole brain concentrations (Figure 2). Mean brain concentrations remained consistently $15-25 \%$ of the plasma concentrations within $4 \mathrm{~h}$ of dosing, yielding a mean brain-to-plasma distribution ratio (plasma/brain AUC) of about 0.2 regardless of the route of administration.

\section{Conclusions}

In summary, we have prepared a number of highly potent antiviral agents with an ethylthioureidic backbone, structurally related to 6-FQXPT. Within the series of QXPTs, the SAR studies led to the identification of 12e, a potent second-generation antiviral agent, in which the benzo-fused ring of the earlier-described QXPTs is replaced by a pyridine ring. Furthermore, in the course of this work we have also investigated the structural dependence of the poor bioavailability and rapid clearance of QXPT compounds, in order to identify antivirals with better oral bioavailability over the known thioureas. Alterations of the mol ecular structure of our QXPTs 6 and $\mathbf{1 2}$ enabled us to develop the quinoxal ine derivative $\mathbf{8}$, a prototype antiviral agent of a new class of RT inhibitors. Its unique structural feature is the presence of a hydrazine group linking the heterocyclic system to the aroyl moiety. Compound 8 represents a new generation inhibitor of HIV-1 replication with potent synergistic antiviral activity with AZT. Preliminary pharmacokinetic studies in the mouse suggest that the QXPT antiviral agents, like other thioureidic antivirals, offer low oral bi oavailability and/ or rapid clearance. In contrast, the new quinoxaline derivative $\mathbf{8}$ has much better pharmacokinetic properties, being rapidly absorbed from the gastrointestinal tract, with mean $\mathrm{C}_{\max }$ of about $7 \mu \mathrm{M}$ after a $20 \mathrm{mg} / \mathrm{kg}$ dose. Although oral bioavailability is about half that after subcutaneous dosing, it remains to be seen whether this is due to an extensive first-pass metabolism or to incomplete absorption from the gastrointestinal tract. Compound $\mathbf{8}$ al so has an intermediate-low $\mathrm{Cl}$ compared to liver blood flow and its $\mathrm{Vd}$ exceeds the total body water volume of the mouse, suggesting extensive uptake into tissue. Although its brain-to-plasma distribution ratio averaged 0.2 after a single dose, it remains to be seen whether it is similar across species because of differences in blood flow, brain size, protein binding, and other mechanisms such as active transport that govern the extent of brain uptake.

\section{Experimental Section}

For general experimental information, see ref 11 . Lactams $\mathbf{9 a}-\mathbf{g}$ used for the synthesis of $\mathrm{N}$-alkylated and O-alkylated compounds were synthesized by using a procedure described in ref 10 , while azides $\mathbf{1 3 h}$,i were previously reported in ref 9 .

General Procedure for Preparation of N-Alkylated Quinoxalinones $10 a-g$ and of O-Alkylated Quinoxaline 13a. This procedure is illustrated for the preparation of 5-(2azi doethyl )-7-fluoropyrrolo[1,2-a]quinoxalin-4(5H)-one (10a) and 4-(2-azidoethoxy)-7-fluoropyrrolo[1,2-a]quinoxaline (13a). To a suspension of sodium hydride $(69.7 \mathrm{mg}, 2.81 \mathrm{mmol}$ ) in anhydrous DMF ( $10 \mathrm{~mL}$ ) was added the pirrol oqui noxal ine $9 \mathrm{a}$ $(0.6 \mathrm{~g}, 2.81 \mathrm{mmol})$ in one portion. The reaction mixture was stirred at room temperature for $2 \mathrm{~h}$, and then tosylethyl azide $(667 \mathrm{mg}, 2.81 \mathrm{mmol}$ ) was added. After $24 \mathrm{~h}$ of stirring at 80 ${ }^{\circ} \mathrm{C}$ the solvent was removed under vacuum, and the residue was dissolved in ethyl acetate. The organic phase was washed with brine, dried, and concentrated. The residue was purified by flash chromatography (ethyl acetate and hexanes, 1:3, as el uant) to afford 13a and 10a as white solids (compound 13a eluted first). After recrytstallization (ethyl acetate and hexanes, 1:3) the $\mathrm{N}$-ethylazide 10a was obtained as colorless prisms. 10a: (59\%) $\mathrm{mp} 133-134{ }^{\circ} \mathrm{C}$; IR (Nujol) 2104, 1653, $1611 \mathrm{~cm}^{-1} ;{ }^{1} \mathrm{H}$ NMR $\left(\mathrm{CDCl}_{3}\right) \delta 3.72(\mathrm{~m}, 2 \mathrm{H}), 4.41(\mathrm{~m}, 2 \mathrm{H})$, $6.66(\mathrm{~m}, 1 \mathrm{H}), 6.95(\mathrm{~m}, 1 \mathrm{H}), 7.15(\mathrm{~m}, 1 \mathrm{H}), 7.25(\mathrm{~m}, 1 \mathrm{H}), 7.66$ $(\mathrm{m}, 2 \mathrm{H})$. Anal. Calcd for $\mathrm{C}_{13} \mathrm{H}_{10} \mathrm{FN}_{5} \mathrm{O}: \mathrm{C}, 57.56 ; \mathrm{H}, 3.72 ; \mathrm{N}$, 25.82. Found: C, 57.57; $\mathrm{H}, 3.69 ; \mathrm{N}, 25.65$.

13a: (20\%) col orless prisms, $\mathrm{mp} 66-67^{\circ} \mathrm{C}$; IR $\left(\mathrm{CHCl}_{3}\right) 2109$ $\mathrm{cm}^{-1}$; ${ }^{1} \mathrm{H}$ NMR $\left(\mathrm{CDCl}_{3}\right) \delta 3.70(\mathrm{~m}, 2 \mathrm{H}), 4.78(\mathrm{~m}, 2 \mathrm{H}), 6.76(\mathrm{~m}$, $1 \mathrm{H}), 6.94(\mathrm{~m}, 1 \mathrm{H}), 7.08(\mathrm{~m}, 1 \mathrm{H}), 7.38(\mathrm{~m}, 1 \mathrm{H}), 7.68(\mathrm{~m}, 1 \mathrm{H})$, $7.78(\mathrm{~m}, 1 \mathrm{H})$. Anal. Calcd for $\mathrm{C}_{13} \mathrm{H}_{10} \mathrm{~F} \mathrm{~N}{ }_{5} \mathrm{O}$ : C, H, N.

General Procedure for Preparation of the Aminoethyl Derivatives $11 \mathbf{a}-\mathbf{g}$ and $\mathbf{1 4 a}-\mathbf{c}$. This procedure is illustrated for the preparation of 5-(2-aminoethyl)-7-fluoropyrrolo[1,2-a]quinoxalin-4(5H)-one (11a).

The azide 10a (112 mg, $0.4 \mathrm{mmol}$ ) was suspended in dry, freshly distilled methanol $(4 \mathrm{~mL})$. The flask was purged with argon, and propane-1,3-dithiol (120 $\mu \mathrm{L}, 1.2 \mathrm{mmol})$ and anhydrous triethylamine $(166 \mu \mathrm{L}, 1.2 \mathrm{mmol})$ were added. The solution was stirred at room temperature for $24 \mathrm{~h}$, the solvent was then removed under vacuum, and the residue was purified by flash chromatography (elution with methanol and triethylamine, 9:1) to obtain 11a as an amorfous solid (89\%). The amine was used in the next step without further purification. IR (Nujol) $1635 \mathrm{~cm}^{-1}$; ${ }^{1} \mathrm{H}$ NMR $\left(\mathrm{CDCl}_{3}\right) \delta 1.5$ (br s, $\left.2 \mathrm{H}\right), 3.05$ $(\mathrm{m}, 2 \mathrm{H}), 4.32(\mathrm{~m}, 2 \mathrm{H}), 6.63(\mathrm{~m}, 1 \mathrm{H}), 6.95(\mathrm{~m}, 1 \mathrm{H}), 7.10(\mathrm{~m}$, $1 \mathrm{H}), 7.20(\mathrm{~m}, 1 \mathrm{H}), 7.55-7.65(\mathrm{~m}, 2 \mathrm{H})$.

General Procedure for Preparation of QXPT Related Compounds $\mathbf{1 2 a}-\mathbf{g}$ and $\mathbf{1 5 a}-\mathbf{c}$. This procedure is illustrated for the preparation of $\mathrm{N}$-[2-(7-fluoro-4-oxopyrrolo[1,2-a]quinoxalin-5-yl)ethyl]-N'-[2-(5-bromopyridyl)]thiourea (11a). To a solution of aminoethylquinoxalinone 11a (127 mg, $0.5 \mathrm{mmol})$ in anhydrous THF (2 mL) was added 2-(5-bromopyridyl)isothiocyanate ( $107 \mathrm{mg}, 0.5 \mathrm{mmol}$ ), and the reaction mixture was stirred at room temperature for $1 \mathrm{~h}$. The resulting precipitate was collected by filtration through a sintered glass filter and washed with another portion of THF. Recrystallization from THF gave 12a (211 mg) as colorless prisms (91\%): mp 256-257 ${ }^{\circ} \mathrm{C}$. IR (Nujol) 3420, $1653 \mathrm{~cm}^{-1}$; ${ }^{1} \mathrm{H}$ NMR $\left(\right.$ DMSO- $\left._{6}\right) \delta 3.95(\mathrm{~m}, 2 \mathrm{H}), 4.48(\mathrm{~m}, 2 \mathrm{H}), 6.70(\mathrm{~m}, 1 \mathrm{H}), 7.04$ $(\mathrm{m}, 3 \mathrm{H}), 7.83(\mathrm{dd}, 1 \mathrm{H}, \mathrm{J}=11.15,2.3 \mathrm{~Hz}), 7.94(\mathrm{dd}, 1 \mathrm{H}$, J $=$ 8.85, 2.1 Hz), $8.14(\mathrm{~m}, 3 \mathrm{H}), 10.74(\mathrm{~b} \mathrm{~s}, 1 \mathrm{H}), 11.35$ (br s, $1 \mathrm{H})$. Anal. Calcd for $\mathrm{C}_{19} \mathrm{H}_{15} \mathrm{BrFN}_{5} \mathrm{OS}: \mathrm{C}, \mathrm{H}, \mathrm{N}$.

N-(Pyrrolo[1,2-a]quinoxalin-4-yl)hydrazine (17). A solution of $\mathbf{1 6}(1.04 \mathrm{~g}, 5.6 \mathrm{mmol})$ and a catalytic amount of N,Ndimethylaniline in phosphorus oxychloride $(16.9 \mathrm{~mL}, 184$ $\mathrm{mmol}$ ) was refluxed under argon for $5 \mathrm{~h}$. After cooling, the excess phosphorus oxychloride was distilled off, and the residue was partitioned between dichloromethane and sodium hydrogencarbonate solution. The organic sol ution was washed with brine, dried, and concentrated. The residue was purified by col umn chromatography (dichloromethane/EtOAc, 9:1) and recrystallized from hexanes to give the 4-chloro intermediate $(0.67 \mathrm{~g}, 59 \%)$ as colorless prisms: $\mathrm{mp} 262-264^{\circ} \mathrm{C}$. This chloro derivative was dissolved in methanol $(15 \mathrm{~mL})$, and the solution was cooled at $0{ }^{\circ} \mathrm{C}$. Then a solution of hydrazine monohydrate $(140 \mu \mathrm{L})$ in methanol (3 $\mathrm{mL})$ was slowly added. After the mixture was stirred for $2 \mathrm{~h}$ at room temperature, the solid was filtered off and the solution was concentrated to give $\mathbf{1 7}$ as a white solid which was recrystallized from methanol $(590 \mathrm{mg}$,

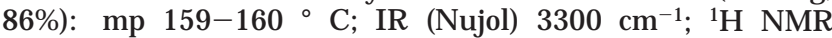
$\left(\mathrm{DMSO}^{\left.-\mathrm{d}_{6}\right)} \delta 4.53(\mathrm{br} \mathrm{s}, 2 \mathrm{H}), 6.68(\mathrm{~m}, 1 \mathrm{H}), 6.89(\mathrm{~m}, 1 \mathrm{H})\right.$, 
$7.30(\mathrm{~m} .2 \mathrm{H}), 7.51(\mathrm{~d}, 1 \mathrm{H}, \mathrm{J}=7.6 \mathrm{~Hz}), 8.05(\mathrm{~d}, 1 \mathrm{H}, \mathrm{J}=7.6$ $\mathrm{Hz}), 8,20(\mathrm{~m}, 1 \mathrm{H}), 8.71(\mathrm{br} \mathrm{s}, 1 \mathrm{H})$. Anal. Calcd for $\mathrm{C}_{11} \mathrm{H}_{10} \mathrm{~N}_{4}$ : C, $\mathrm{H}, \mathrm{N}$.

4-(5-Bromopyridin-2-yl)-1-(pyrrolo[1,2-a]quinoxalin-4yl)semicarbazide (18a). To a soluti on of triphosgene (54 mg, $0.85 \mathrm{mmol})$ in anhydrous dichloromethane $(1 \mathrm{~mL})$ was added a solution of 2-amino-5-bromopyridine ( $86 \mathrm{mg}, 0.5 \mathrm{mmol}$ ) and diisopropylethylamine $(192 \mu \mathrm{L}, 1.1 \mathrm{mmol})$ in anhydrous dichloromethane $(1 \mathrm{~mL})$. After the mixture was stirred for 5 min at room temperature, a solution of 17 (100 $\mathrm{mg}, 0.5 \mathrm{mmol})$ in anhydrous dichloromethane $(1 \mathrm{~mL})$ was added. The resulting solution was stirred at room temperature overnight. The solvent was evaporated, and the residue was taken up in EtOAc. The organic layer was washed with brine, dried, and concentrated. The residue was purified by chromatography (dichlorometane and $10 \%$ methanol and 1\% ammonium hydroxide) to give a yellow solid which was recrystallized (EtOAc) to give $73 \mathrm{mg}(41 \%)$ of 18 a as yellow prisms: $\mathrm{mp} 114-115^{\circ}$ C. IR (Nujol) 3410, $1653 \mathrm{~cm}^{-1} ;{ }^{1} \mathrm{H}$ NMR (DMSO-d 6 ) $\delta 6.06$ (s, $1 \mathrm{H}), 6.45(\mathrm{~d}, 1 \mathrm{H}, \mathrm{J}=6.6 \mathrm{~Hz}), 7.22(\mathrm{~m}, 4 \mathrm{H}), 7.59(\mathrm{~m}, 1 \mathrm{H})$, $8.02(\mathrm{~m}, 3 \mathrm{H}), 9.98(\mathrm{br} \mathrm{s}, 1 \mathrm{H}), 10.11(\mathrm{br} \mathrm{s}, 1 \mathrm{H}), 11.64(\mathrm{br} \mathrm{s}, 1$ $\mathrm{H})$. Anal. Calcd for $\mathrm{C}_{17} \mathrm{H}_{13} \mathrm{BrN}_{6} \mathrm{O}: \mathrm{C}, \mathrm{H}, \mathrm{N}$.

4-(5-Bromopyridin-2-yl)-1-(pyrrolo[1,2-a]quinoxalin-4yl)thiosemicarbazide (18b). Starting from 17, the title compound was obtained following the synthetic procedure described in ref 9. Compound $\mathbf{1 8 b}$ was obtained as yellow prisms (41\%): $\mathrm{mp} 236-237^{\circ} \mathrm{C}$. IR (Nujol) 3410, $1620 \mathrm{~cm}^{-1}$; ${ }^{1} \mathrm{H}$ NMR (DMSO-d 6 ) $\delta 6.80-7.59(\mathrm{~m}, 5 \mathrm{H}), 7.80-8.70(\mathrm{~m}, 4$ H), 9.97 (br s, 1 H), 10.62 (br s, 1 H), 10.91 (br s, 1 H). Anal. Calcd for $\mathrm{C}_{17} \mathrm{H}_{13} \mathrm{BrN}_{6} \mathrm{~S}$ : C, H, N.

N-(Pyrazinecarbonyl)-N'-(pyrrolo[1,2-a]quinoxalin-4yl)hydrazine (8). To a magnetically stirred suspension of pyrazinecarboxylic acid (31 $\mathrm{mg}, 0.25 \mathrm{mmol}$ ) in anhydrous dichloromethane ( $1 \mathrm{~mL}$ ) were added, porti onwise within $1 \mathrm{~h}$, triphenylphosphine (132 mg, $0.5 \mathrm{mmol}$ ) and 2,2'-dipyridyl disulfide (Aldrithiol-2) (111 mg, $0.5 \mathrm{mmol}$ ), and the disappearance of the starting material was monitored by TLC (EtOAC). Then a solution of 17 (50 mg, $0.25 \mathrm{mmol}$ ) in anhydrous dichlometane ( $3 \mathrm{~mL}$ ) was added, and the reaction mixture was stirred overnight at room temperature. The solvent was removed, and the residue was taken up in a mixture of EtOAc and $5 \%$ hydrochl oric acid. The organic phase was washed with $1 \mathrm{~N}$ sodium hydroxide and brine, dried, and concentrated. The residue was chromatographed (dichlorometane and $10 \%$ methanol and $1 \%$ ammonium hydroxide) to give a yellow solid which was recrystallized (EtOAc) to give $45 \mathrm{mg}$ of $\mathbf{8}$ as yellow prisms: $\mathrm{mp} 216-218^{\circ} \mathrm{C}$; IR (Nujol) $3420,1653 \mathrm{~cm}^{-1}$; ${ }^{1} \mathrm{H}$ NMR $\left(\mathrm{DMSO}^{\mathrm{d}} \mathrm{d}_{6}\right) 6.83(\mathrm{~s}, 1 \mathrm{H}), 7.20-7.30(\mathrm{~m}, 3 \mathrm{H}), 7.44(\mathrm{~m}, 1 \mathrm{H})$, $8.13(\mathrm{~m}, 1 \mathrm{H}), 8.34(\mathrm{~s}, 1 \mathrm{H}), 8.87(\mathrm{~s}, 1 \mathrm{H}), 8.98(\mathrm{~s}, 1 \mathrm{H}), 9.25(\mathrm{~s}$, $1 \mathrm{H}), 9.65(\mathrm{br} s, 1 \mathrm{H}), 10.96(\mathrm{br} s, 1 \mathrm{H})$. Anal. Calcd for $\mathrm{C}_{16} \mathrm{H}_{12} \mathrm{~N}_{6} \mathrm{O}: \mathrm{C}, \mathrm{H}, \mathrm{N}$.

N-(Pyrazinecarbonyl)-N'-(pyrrolo[1,2-a]quinoxalin-4yl)hydrazine (19). Following a synthetic procedure similar to that described for $\mathbf{1 8 a}$, using pyridine-2-carboxylic acid, the title compound was obtained in $68 \%$ yiel d as colorless prisms: mp 148-149 ${ }^{\circ} \mathrm{C}$; IR (Nujol) 3420, $1635 \mathrm{~cm}^{-1} ;{ }^{1} \mathrm{H} \mathrm{NMR}\left(\mathrm{CDCl}_{3}\right)$ $\delta 6.86(\mathrm{~m}, 1 \mathrm{H}), 7.10-7.25(\mathrm{~m}, 3 \mathrm{H}), 7.40-7.50(\mathrm{~m}, 2 \mathrm{H}), 7.83$ $(\mathrm{m}, 1 \mathrm{H}), 8.19(\mathrm{~m}, 1 \mathrm{H}), 8.46-8.74(\mathrm{~m}, 2 \mathrm{H}), 9.03-9.35(\mathrm{~m}, 2$ $\mathrm{H}), 10.16$ (br S, $1 \mathrm{H}$ ). Anal. Calcd for $\mathrm{C}_{17} \mathrm{H}_{13} \mathrm{~N}_{5} \mathrm{O}: \mathrm{C}, \mathrm{H}, \mathrm{N}$.

Molecular Modeling. Molecular modeling studies were performed using the SYBYL software package ${ }^{19}$ running on a Silicon Graphics I ris I ndigo R10000 workstation. The crystal structure of the RT/nevirapine complex solved at $2.2 \AA$ resolution by Ren et al. was retrieved from the Brookhaven Protein Data Bank ${ }^{27}$ (entry code 1VRT).

I ntramolecular and intermolecular energies were calculated using the molecular mechanics Tripos force field including the electrostatic contribution. Atom centered partial charges were calculated according to the Gasteiger-Hückel method.28,29 Geometry optimizations were realized with the SYBYL/MAXIMIN2 minimizer by applying the BFGS algorithm ${ }^{30}$ and setting a root-mean-square gradient of the forces acting on each atom at $0.1 \mathrm{kcal} / \mathrm{mol} \AA$ as a convergence criterion.

Models of compounds $\mathbf{8}$ and 15a were built according to standard distances and valence angles of the Tripos force field. By manually modifying the torsion angles about the $\mathrm{CAr}-\mathrm{N}$ and $\mathrm{N}-\mathrm{N}$ rotatable bonds of $\mathbf{8}$, we found a butterfly-like orientation of this ligand superimposable on nevirapine about the aromatic systems (corresponding to the butterfly wings): the pyrroloquinoxal ine $B$ ring and the pyrazine ring of $\mathbf{8}$ were matched with the pyridine $A$ and $B$ rings of nevirapine, respectively. The fitting points were, more specifically, pseudoatoms placed at $1 \AA$ along the normals to the plane of each aromatic ring passing through the ring centroid.

The so-obtained pharmacophore-based conformation of $\mathbf{8}$ was then placed into the NNRTI binding cl eft extracted from the crystal structure of the RT/nevirapine complex. The binding site comprised 71 amino acids located within a distance of $10 \AA$ from any non-hydrogen atom of the bound inhibitor. Water molecules were deleted. Hydrogens were added to the unfilled valences of the amino acids, and the Lys, Asp, and Glu side chains were modeled in their ionized forms.

The trial RT/8 complex was first geometry-optimized by keeping fixed the coordinates of the protein. The resulting (highly distorted) geometry of the ligand was energy-minimized al one while retaining the conformation of the spacer through appropriate constraints applied to torsional angles. The optimized output geometry of the ligand was then placed into the NNRTI binding site through an overlay on the corresponding input geometry about non-hydrogen atoms. Finally, the complex was fully energy-minimized by keeping fixed the protein backbone until an attractive energy of $25 \mathrm{kcal} /$ mol was reached. This protocol did not produce significant changes in the starting structure.

A model of the RT/15a complex was obtained by following a computational procedure similar to the one described above.

To check whether the RT-bound conformations of 8 and $\mathbf{1 5 a}$ were energetically feasible, they were fully geometry optimized in vacuo. The resulting nearest local minimum conformers revealed to be more stable by 1.3 and, respectively, $3.1 \mathrm{kcal} /$ $\mathrm{mol}$, meaning that the input geometries were not affected by steric conflicts.

HIV-1 RT RNA-dependent DNA Polymerase Activity Assay. Inhibition Assay. RNA-dependent DNA polymerase activity assay was assayed as follows: a final volume of 25 $\mu \mathrm{M}$ contained reaction buffer $(50 \mathrm{mM}$ Tris- $\mathrm{HCl} \mathrm{pH} 7.5,1 \mathrm{mM}$ DTT, $0.2 \mathrm{mg} / \mathrm{mL}$ BSA, $4 \%$ glycerol), $10 \mathrm{mM} \mathrm{MgCl} 2,0.5 \mu \mathrm{g}$ of poly(rA)oligo(dT) $)_{10: 1}\left(0.3 u \mathrm{M}\right.$ 3'-OH ends), $10 \mu \mathrm{M}$ [3 ${ }^{3}$ ] -dTTP (1 $\mathrm{Ci} / \mathrm{mmol})$, and 2-4 nM RT. Reactions were incubated at 37 ${ }^{\circ} \mathrm{C}$ for the indicated time. A total of $20 \mu \mathrm{L}$ aliquots were then spotted on glass fiber filters GF/C which were immediately immersed in 5\% ice-cold TCA. Filters were washed twice in $5 \%$ ice-cold TCA and once in ethanol for $5 \mathrm{~min}$ and dried, and acid-precipitable radioactivity was quantitated by scintillation counting. 31

Reactions were performed under the conditions described for the HIV-1 RT RNA-dependent DNA polymerase activity assay. Incorporation of radioactive dTTP into poly(rA)/oligo(dT) was monitored in the presence of increasing amounts of the inhibitors to be tested. Data were then plotted according to Lineweaver-Burke and Dixon. F or $K_{i}$ determinations, an interval of inhibitor concentrations between $0.2 \mathrm{~K}_{i}$ and $5 \mathrm{~K}_{i}$ was used. Experiments have been done in triplicate. Experimental errors ( \pm SD) were $\leq 10 \%$.

In Vitro Anti-HIV Assays. Cell Culture Assay. 1. CEM Cell Line. The ability of the test compounds to protect HIV-1 infected T4 Iymphocytes (CEM cells) from cell death was determined following the reported procedure. ${ }^{32}$ All compounds were compared with a positive (AZT-treated) control performed at the same time under identical conditions.

2. Other Cells. Mature macrophages were obtained by incubating in 48-well plates (Costar, Cambridge, MA) $10^{6}$ $\mathrm{PBMC} / \mathrm{mL}$ of complete medium (containing Roswell Park Memorial Institute (RPMI)-1640, penicillin 100 units $/ \mathrm{mL}$, streptomycin $100 \mathrm{mg} / \mathrm{mL}$, L-glutamine $0.3 \mathrm{mg} / \mathrm{mL}$ and $20 \%$ heat inactivated fetal calf serum). After 7 days of incubation in $5 \% \mathrm{CO}_{2}$ at $37{ }^{\circ} \mathrm{C}$, nonadherent cells (lymphocytes) were removed by extensive washing. Using this method, the yield, 
after removal of the nonadherent cells, was $10^{5}$ macrophages per well. Test was conducted as described elsewhere. ${ }^{33}$ Macrophages obtained with this method are $>95 \%$ pure as detected by nonspecific esterase activity. C8166 is a CD4 ${ }^{+} \mathrm{T}$-cell line containing an HTLV-I genome of which only the tat gene is expressed. ${ }^{34}$

3. Virus. A laboratory lymphocyte-tropic strain of HIV-1 (HIV-1-IIIB) was used to infect C8166, while macrophages were infected with a laboratory monocyte-tropic strain of HIV-1 (HTLV-III-Ba-L, also called HIV-Ba-L). ${ }^{35,36}$ Titration to determine the infectivity was performed in human macrophages as previously described. The titer of the virus stocks, expressed as $50 \%$ tissue culture infectious dose $\left(T_{C I} D_{50}\right)$, was determined as previously described. ${ }^{37}$

4. Antiviral Agent. Zidovudine (AZT) was purchased from Sigma Chimica.

5. Toxicity. Chemicals toxicity in C8166 was evalueted with a procedure involving a colorimetric assay (MTT assay) that monitors the ability of viable, but not dead, cells to reduce 3-(4,5-dimethylthiazol-2-yl)-2,5-diphenyltetrazolium bromide (MTT) to a blue formazan product, which can be measured spectrophotometrically. ${ }^{38,39}$

6. Assay of Antiviral Activity. Antiviral activity of the tested compounds in acutely infected C8166 cultures was performed following an already described procedure. ${ }^{9}$ The assay to evaluate anti-HIV drug efficacy in acutely infected mature macrophages has been previously described. 33 The antiviral activity of the compounds was assessed by measuring HIV-p24 antigen production in the supernatants of infected cultures as previously described ${ }^{35}$ by using a commercially available HIV-antigen kit.

7. Immunofluorescence Virus Binding Assay. Calculation of the $50 \%$ effective dose $\left(E D_{50}\right)$ and $50 \%$ inhibitory dose $\left(I D_{50}\right)$ was performed. The $E D_{50}$ and ID 50 values were calculated from pooled values in the effective dynamic range of the antiviral and toxicity assays (5-95\%) using the median effect equation as previously described. ${ }^{40}$

Toxicity Tests. 1. Cell Lines. All cell lines were obtained from ATCC. The cells were cultured in RPMI 1640 supplemented with $5 \% \mathrm{FCS}, 0.1 \mathrm{mM}$ glutamine, $1 \%$ penicillin, and streptomycin. Cells were grown in Nunc clone plastic bottles (TedNunc, Roskilde, Denmark) and split twice weekly at different cell densities according to standard procedure. 3T3 cells were grown as a monolayer and were split by using tripsin. Perypheral blood mononuclear cells (MNC) were separated from heparinized whole blood obtained from a healthy donor on a Fycoll-Hypaque gradient as previously described. ${ }^{41}$ MNC thus obtained were washed twice with RPMI 1640 supplemented with $10 \%$ FCS, glutamine, and antibiotics, suspended at 200.000 viable cells/mL in medium containing, as mitogen, $5 \mu \mathrm{g} / \mathrm{mL}$ PHA (Sigma) and used in toxicity tests.

2. Chemicals. MTT (3-(4,5-dimethylthiazol-2-yl)-2,5-diphenyltetrazolium bromide) was purchased from Aldrich. It was dissolved at a concentration of $5 \mathrm{mg} / \mathrm{mL}$ in sterile PBS at room temperature, and the solution was further sterilized by filtration and stored at $4{ }^{\circ} \mathrm{C}$ in a dark bottle. SDS was obtained from Sigma. Lysis buffer was prepared as follows: $20 \% \mathrm{w} / \mathrm{v}$ of SDS was dissolved at $37{ }^{\circ} \mathrm{C}$ in a solution of $50 \%$ of each DMF and demineralized water; $\mathrm{pH}$ was adjusted to 4.7 by adding $2.5 \%$ of an $80 \%$ acetic acid and $2.5 \% 1 \mathrm{~N} \mathrm{HCl}$ solution.

3. Toxicity Experiments. Cells were plated at different concentrations on flat bottom 96-well microplates $(0.1 \mathrm{~mL} /$ well). Lymphocytes were plated out at $20000 \mathrm{cells} /$ well. 3T3 cells (murine fibroblast line) were plated at 10000 cells/well. NSO cells (plasmocytoma murine cell line) were plated out at 3000 cells/well, and Daudi cells (human Iymphoblastoid cell line) were plated at 300 cells/well. Twelve hours after plating, different concentrations of each compound were added to each well. After 48 h, MTT assay was performed to analyze cytotoxicity of the different compounds. Some experiments were performed by using confluent cells: compounds were added to the 3T 3 monolayer 3 days after plating. Tests were then run as described above.

4. MTT/Formazan Extraction Procedure. A total of 20 $\mu \mathrm{L}$ of the $5 \mathrm{mg} / \mathrm{mL}$ stock solution of MTT was added to each well; after $2 \mathrm{~h}$ of incubation at $37{ }^{\circ} \mathrm{C}, 100 \mu \mathrm{L}$ of the extraction buffer was added. After an overnight incubation at $37^{\circ} \mathrm{C}$, the optical densities at $570 \mathrm{~nm}$ were measured using a Titer-Tech 96-well multiscanner, employing the extraction buffer as the blank.

Synergy Calculations. The multiple drug effect analysis of Chou and Talalay ${ }^{42}$ was used to calculate combined drug effects.

Drug Analysis. ${ }^{8 b}$ Plasma and brain concentrations of the test compounds were determined by high-performance liquid chromatography (HPLC). An internal standard (IS) was used in each assay. Brain concentrations of $\mathbf{8}$ were not corrected for the compound contributed by residual blood because, in terms of concentrations, this amounted only to $5-10 \%$ of the brain concentrations.

Acknowledgment. We are grateful to the Istituto Superiore di Sanita', Roma, Italy, for financial support (Progetto Patogenesi, Immunita' e Vaccino, Grant No. 40B.69) and to Universita' di Siena (PAR 99). Furthermore, this work has been partially supported by the ISSProgramma Nazionale di Ricerca sull' AIDS (Contract 30C.70) and by the CNR Target Project on Biotechnology to S.S. Authors thank Dr. Massimo Pregnolato (Dipartimento di Chimica Farmaceutica, Universita' di Pavia) for a gift of efavirenz.

Supporting Information Available: Experimental de tails relative to synthesis and physical and chemical data of compounds 11-15, to synergy calculations, and to drug administration and plasma and brain sampling/drug analysis, and a table with elemental analyses of compounds $\mathbf{8}, \mathbf{1 2 a}-\mathbf{g}$, $\mathbf{1 5 a}-\mathbf{c}, \mathbf{1 8 a}, \mathbf{b}$ and $\mathbf{1 9}$. This material is available free of charge via the Internet at http://pubs.acs.org.

\section{References}

(1) (a) Barre'-Sinoussi, F.; Chermann, J . C.; Rey, F.; Nugeyre, M .; Chamaret, S.; Gruest, J .; Dauguet, C.; Axlar-Blin, C.; VezinetBrun, F.; Rouzioux, C.; Rozenbaum, W.; Montagner, L. I solation of a T-lymphotropic Retrovirus from a Patient at Risk for Acquired I mmune Deficiency Syndrome. Science 1983, 220, 868871. (b) Gallo, R. C.; Sarin, P. S.; Gelman, E. P.; Robert-Guroff, M.: Richardson, E.; Kalyanaraman, V. S.; Mann, D.; Sidhu, G. D.; Stahl, R. E.; Zolla-Pazner, S.; Leibowitch, J.; Popovic, M. I solation of Human T-Cell Leukemia Virus in Acquired I mmune Deficiency Syndrome (AIDS). Science 1983, 220, 865-867.

(2) (a) Conolly, K. J .; Hammer, S. M.; Antiretroviral Therapy: Reverse transcriptase Inhibition. Antimicrob. Agents Chemother. 1992, 36, 245-254. (b) Sandstrom, E.; Oberg, B.; Antiviral Therapy in Human I mmunodeficiency Virus I nfections. Drugs 1993, 45, 488-508.

(3) (a) Pauwels, R.; Andries, K.; Desmyter, J .; Schols, D.; Kukla, M. J .; Breslin, H. J .; Raeymaeckers, A.; Van Gelder, J .; Woestenborghs, R.; Heykants, J.; Schellekens, K.; J anssen, M. A. C.; De Clercq, E.; J anssen, P. A. J . Potent and Selective Inhibition of HIV-1 Replication In Vitro by a Novel Series of TIBO Derivatives. Nature 1990, 343, 470-474. (b) Breslin, H. J. Kukla, M. J .; Ludovici, D. W.; Mohrbacher, R.; Ho, W.; Miranda, M.; Rodgers, J . D.; Hitchens, T. K.; Leo, G.; Gauthier, D. A.; Ho, C. Y.; Scott, M. K.; De Clercq, E.; Pauwels, R.; Andries, K. J anssen, M. A. C.: J anssen, P. A. J Synthesis and Anti-HIV-1 Activity of 4,5,6,7-Tetrahydro-5-methylimidazo[4,5,1-jk][1,4]benzodiazepin-2(1H)-one (TIBO) Derivatives. J . Med. Chem. 1995, 38, 771-793.

(4) (a) Hargrave, K. D.; Proudfoot, J . R.; Grozinger, K. G.; Cullen, E.; Kapadia, S. R.; Patel, U. R.; Fuchs, V. U.; Mauldin, S. C.; Vitous, J .; Behnke, M. L.; Klunder, J . M.; Pal, K.; Skiles, J. W. McNeil, D. W.; Rose, J . M.; Chow, G. C.; Skoog, M. T.; Wu, J. C.; Schmidt, G.; Engel, W. W.; Eberlein, W. G.; Saboe, T. D.; Campbell, S. J .; Rosenthal, A. S.; Adams, J. Novel NonNucleoside Inhibitors of HIV-1 Reverse Transcriptase. 1. Tricyclic Pyridobenzo- and Dipyridodiazepinones. J. Med. Chem. 1991, 34, 2231-2241 and references therein. (b) Cohen, K. A. Hopkins, J .; Ingraham, R. H.; Pargellis, G.; Wu, J . C.; Palladino, D. E. H.; Kinkade, P.; Warren, T. C.; Rogers, S.; Adams, J .; Farina, P. R.: Grob, P. M. Characterization of the Binding Site of Nevirapine (BI-RG-587), a Non-Nucleoside Inhibitor of Human I mmunodeficiency Virus Type-1 Reverse Transcriptase. J . Biol Chem. 1991, 266, 14670-14674. (c) Klunder, J . M.; Hargrave 
K. D.; West, M.; Cullen, E.; Pal, K.; Behnke, M. L.; Kapadia, S. R.; McNeil, D. W.; Wu, J . C.; Chow, G. C.; Adams, J . Novel NonNucleoside I nhibitors of HIV-1 Reverse Transcriptase. 2. Tricyclic Pyridobenzoxazepinones and Dibenzoxazepinones. J . Med. Chem. 1992, 35, 1887-1897.

(5) Bell, F. W.; Cantrell, A. S.; Hogberg, M.; J askunas, R.; J ohansson, N. G.; J ordan, C. L.; Kinnick, M. D.; Lind, P.; Morin, J . M., J r.; Noreen, R.; Oberg, B.; Palkovitz, J . A.; Parrish, C. A.; Pranc P.; Sahlberg, C.; Ternansky, R. J .; Vasileff, R. T.; Vrang, L.; West, S. J .; Zhang, H.; Zhou, X.-X. Phenetylthiazolethiourea (PETT) Compounds, a New Class of HIV-1 Reverse Transcriptase I nhibitors. 1. Synthesis and Basic Structure-Activity Relationship Studies of PETT Analogues. J . Med. Chem. 1995, 38, 4929-4936.

(6) Ahgren, C.; Backro, K.; Bell, F. W.; Cantrell, S.; Clemens, M.; Colacino, J. M.; Deter, J. B.; Engelhardt, J. A.; Ogberg, M.; J askunas, S. R.; J onhansson, N. G.; J ordan, C. L.; Kasher, J. S.; Kinnik, M. D.; Lind, P.; Lopez, C.; Morin, J r, J . M.; Muesing M. A.; Noreen, R.; Oberg, B.; Pagget, C. J .; Palkowitz, J . A.; Parrish, C. A.; Pranc, P.; Rippy, M. K.; Rydergard, C.; Sahl berg, C.; Swanson, S.; Ternansky, R. J .; Unge, T.; Vasileff, R. T.; Wrang, L.; West, S. J .; Zhang, H.; Zhou, X.-X. The PETT Series, a New Class of Potent Nonnucleoside Inhibitors of Human Immunodeficiency Virus Type 1 Reverse Transcriptase. Antimicrob. Agents Chemother. 1995, 39, 1329-1335.

(7) (a) Cantrell, S. A.; Engel hardt, P.; Hogberg, M.; J askunas, S. R.; J ohansson, N. G.; J ordan, C. L.; Kangasmetsa, J .; Kinnik, M. D.; Lind, P.; Morin, J r, J . M.; Muesing, J r, J . M.; Noreen, R.; Oberg, B.; Pranc, P.; Sahl berg, C.: Ternansky, R. J.; Vasileff, R. T.; Wrang, L.; West, S. J .; Zhang, H. Phenetylthiazol ethiourea (PETT) Compounds, as a New Class of HIV-1 Reverse Transcriptase Inhibitors. 2. Synthesis and Further StructureActivity Relationship Studies of PETT Analogues. I . Med. Chem. 1996, 39, 4261-4274. (b) While this manuscript was in preparation, a paper by Högberg et al. was published disclosing two crystal structures of RT complexed with enantiomeric cyclopropyl-ureas closely related to the NNRTI trovirdine. Our model of the RT/15a complex was found in good agreement with the structures reported by these authors as far as the overall ligand conformation and main intermolecular interactions are concerned: Högberg, M.; Sahlberg, C.; Engel hardt, P.; N oéen, R. Kangasmetsä, J .; J ohansson, N. G.; Öberg, B.; Vrang, L.; Zhang H.; Sahlberg, B.-L.; Unge, T.; Lövgren, S.; Fridborg, K.; Bäckbro, K. Urea-PETT Compounds as a New Class of HIV-1 Reverse Transcriptase Inhibitors. 3. Synthesis and Further StructureActivity Relationship Studies of PETT Analogues. J . Med. Chem. 1999, 42, 4150-4160

(8) (a) Campiani, G.; Nacci, V.; Fiorini, I.; De Filippis, M. P.; Garofalo, A.; Greco, G.; Novellino, E.; Altamura, S.; Di Renzo, L. Pyrrolobenzothiazepinones and Pyrrolobenzoxazepinones: Novel and Specific Non-Nucleoside HIV-1 Reverse Transcriptase Inhibitors with Antiviral Activity. J. Med. Chem. 1996, 39, 2672-2680. (b) Campiani, G.; M orelli, E.; Fabbrini, M.; Nacci, V.; Greco, G.; Novellino, E.; Ramunno, A.; Maga, G.; Spadari, S.; Caliendo, G.; Bergamini, A.; Faggioli, E.; Uccella, I.; Bolacchi, F.; Marini, S.; Col etta, M.; Nacca, A.; Caccia, S. Pyrrol obenzoxazepinone Derivatives as N on-Nucleoside HIV-1 RT I nhibitors: Further Structure-Activity Relationship Studies and Identification of More Potent Broad-Spectrum HIV-1 RT I nhibitors with Antiviral Activity. J. Med. Chem. 1999, 42, 4462-4470.

(9) Campiani, G.; Fabbrini, M.; Morelli, E.; Nacci, V.; Greco, G.; Novellino, E.; Ramunno, A.; Maga, G.; Spadari, S.; Bergamini, A.; Faggioli, E.; Uccella, I.; Bolacchi, F.; Marini, S.; Col etta, M.; Fracasso, C.; Caccia, S. Non-Nucleoside HIV-1 Reverse Transcriptase Inhibitors: Synthesis and Biological Evaluation of Novel Quinoxalinylethylpyridylthioureas as Potent Antiviral Agents. Antivir. Chem. Chemother. 2000, 11, 141-155.

(10) Campiani, G.; Cappelli, A.; Nacci, V.: Anzini, M.; Vomero, S. Hamon, M.; Cagnotto, A.; Fracasso, C.; Uboldi, C.; Caccia, S.; Consolo, S.; Mennini, T. Novel and Highly Potent 5-H $\mathrm{H}_{3}$ Receptor Agonists Based on a Pyrroloquinoxaline Structure. J . Med. Chem. 1997, 40, 3670-3678.

(11) Campiani, G.; Morelli, E.; Nacci, V.; Gemma, S.; Butini, S.; Hamon, M.; Novellino, E.; Greco, G.; Cagnotto, A.; Goegan, M.; Cervo, L.; Dalla Valle, F.; Fracasso, C.; Caccia, S.; Mennini, T. Pyrroloquinoxaline Derivatives as a New Class of Potent and Selective 5- $\mathrm{HT}_{3}$ Receptor Agonists. Synthesis, Further StructureActivity Relationships, and Biological Studies. J. Med. Chem. 1999, 42, 4362-4379.

(12) Davey, D. D.; Erhardt, P. W.; Cantoe, E. H.; Greenberg, S. S.; Ingebretsen, W. R.; Wiggins, J. Novel Compounds Possessing Potent CAMP and cGMP Phosphodiesterase Inhibitory Activity. Synthesis and Cardiovascular Effects of a Series of I midazo[1,2 a]quinoxalinones and I midazo[1,5-a]quinoxalinones, and Their Aza Analogues. J. Med. Chem. 1991, 34, 2671-2677.

(13) Prunier, H.; Rault. S.; Lancel ot, J .-C.; Robba, M.; Renard, P.; Delagrange, P.; Pfeiffer, B.; Caignard, D.-H.; Misslin, R.; Guardiola-Lemaitre, B.; Hamon, M. Novel and Selective Partial Ago- nists of 5-HT 3 Receptors. 2. Synthesis and Biological Evaluation of Piperazinopyridopyrrolopyrazines, Piperazinopyrroloquinoxalines, and Piperazinopyridopyrroloquinoxalines. J . Med. Chem 1997, 40, 1808-1819.

(14) McQuaid, L. A.; Smith, E.; South, K.; Mitch, C. H.; Schoepp, D. True, R. A.; Calligaro, D. O.; O'Malley, P. J. Synthesis and Excitatory Amino acids Pharmacology of a Series of HeterocyclicFused Quinoxalinones and Quinazolinones. J . Med. Chem. 1992 35, 3319-3324.

(15) Campiani, G.; Sun, L.-Q.; Kozikowski, A. P.; Aagaard, P.; Mckinney, M. A Palladium-Catalyzed Route to Huperzine A and Its Analogues and Their Acetylcholinesterase Activity. J . Org. Chem. 1993, 58, 7660-7669.

(16) Di Fabio, R.; Summa, V.; Rossi, T. Synthesis of Amides: An Efficient and Chemoselective Method for the Preparation of $\beta$-Lactam Derivatives Related to HLE Inhibitors. Tetrahedron 1993, 49, 2299-2306.

(17) Ren, J.; Esnouf, R.; Garman, E.; Somers, D.; Ross, C.; Kirby, I.; Keeling, J .; Darby, G.; J ones, Y.; Stuart, D.; Stammers, D. HighResolution Structures of HIV-RT from four RT-I nhibitor Complexes. Nature Struct. Biol. 1994, 2, 293-302.

(18) Clark, M.; Cramer, R. D., III.; Van Opdenbosch, N. Validation of the General Purpose Tripos 5.2 Force Field. J . Comput. Chem 1989, 10, 982-1012.

(19) SYBYL Molecular Modeling System (version 6.2); Tripos Inc.: St. Louis, MO.

(20) Mager, P. P. Evidence of a Butterfly-Like Configuration of Structurally Diverse Allosteric I nhibitors of the HIV-1 Reverse Transcriptase. Drug Des. Discovery 1996, 14, 241-257.

(21) De Clercq, E. Toward Improved Anti-HIV Chemotherapy: Therapeutic Strategies for Intervention with HIV Infections. J . Med. Chem. 1995, 38, 2491-2517.

(22) Ho, D. D.; Rota, T. R.; Schooley, R. T.; Kaplan, J. C.; Allan, J. D.; Groupman, J. E.; Resnick, L.; Felsenstein, D.; Andrews, C. A.; Hirsch, M. S. I solation of HTLV-III from Cerebrospinal Fluid and Neural Tissues of Patients with Neurological Syndrome. N. Engl. J . Med. 1985, 313, 1493-1497.

(23) Resnick, L.; Berger, J . R.; Shapshak, P.; Tourtellotte, W. W. Early Penetration of the Blood-Brain Barrier by HIV. Neurology 1988, 38, 9-14

(24) Portegies, P. HIV-1, the Brain, and Combination Therapy. The Lancet 1995, 346, 1244-1245.

(25) Levin, V. A. Relationship of Octanol/water Partition Coefficient and Molecular Weight to Rat Brain Permeability. J . Med. Chem. 1980, 23, 682-688.

(26) (a) Chikale, E. G.; Ng, K. Y.; Burton, P. S.; Borchardt, R. T.; Hydrogen Bonding Potential as a Determinant of the in Vitro and in Situ Blood-Brain Barrier Permeability of Peptides. Pharm. Res. 1994, 11, 412-419. (b) ClogP program, version 2.0: Biobyte Corp.: Claremont, CA.

(27) Bernstein, F. C.; Koetzle, T. F.; Williams, G.J . B.; Meyer, E. F. I r.; Brice, M. D.; Rodgers, J. R.; Kennard, O.; Shimanouchi, T. Tasumi, T. The Protein Data Bank: A Computer Based Archival File for Macromolecular Structures. J. Mol. Biol. 1977, 112 535-542.

(28) Gasteiger, J .; Marsili, M. Iterative Partial Equalization of Orbital Electronegativity. Tetrahedron 1980, 36, 3219-3228.

(29) Purcel, V. P.: Singer, J. A. A Brief Review and Table of Semiempirical Parameters Used in the Hückel Molecular Orbital Method, J . Chem. Eng. Data 1967, 12, 235-246.

(30) Head, J .; Zerner, M. C. A Broyden-Fletcher-Goldfarb-Shanno Optimization Procedure for Molecular Geometries. Chem. Phys. Lett. 1985, 122, 264-274.

(31) Maga, G.; Amacker, M.; Ruel, N.; Hubsher, U.; Spadari, S. Resistance to Nevirapine of HIV-1 Reverse Transcriptase Mutants: Loss of Stabilizing Interactions and Thermodynamic or Steric Barriers are Induced by Different Single Amino Acid Substitutions. I. Mol. Biol. 1997, 274, 738-747.

(32) Weislow, O. W.; Kiser, R.; Fine, B.; Bader, J .; Shoemaker, R.; Boyd, M. R. New Soluble-formazan Assay for HIV-1 Cytopathic Effects: Application of High-flux Screening of Synthetic and Natural Products for AIDS-antiviral Activity. J . Natl. Cancer Inst. 1989, 81, 577-586.

(33) Perno, C. F.: Yarchoan, R.: Cooney, D.A. Inhibition of Human I mmunodeficiency Virus (HIV-1/HTLV-III-Ba-I) Replication in Fresh and Cultured Human Peripheral Blood Monocytes/Macrophages by Azidothymidine and Related 2',3'-Dideoxynucleosides. J . Exp. Med. 1988, 168, 1111-1125.

(34) Sodroski, J . G.; Rosen, C. A.; Haseltine, W. A. Trans-acting Transcriptional Activation of the Long Terminal Repeat of Human T Lymphotropic Viruses in I nfected Cells. Science 1984, 225, 381-385.

(35) Popovic, M.; Sarngadharen, M. G.; Read., E.; Gallo, R. C. Detection, Isolation and Continuos Production of Cytopathic Retrovirus (HTLV-III) from Patients with AIDS and pre-AIDS. Science 1984, 224, 497-500. 
(36) Gartner, S.; Markovits, P.; Markovitz, D. M.; Kaplan, M. H.; Gallo, R. C.; Popovic, M. The Role of Mononuclear Phagocytes in HTLV-III/LAV I nfection. Science 1986, 233, 1533-1544.

(37) Karber, G.; Beitrag zur Kollektiven Behandlung Pharmakologischer'Reihenversuche. Arch. Exp. Pharmakol. 1931, 162, 480483.

(38) Bergamini, A.; Perno, C. F.; Capozzi, M. A Tetrazolium-Based Colorimetric Assay for Quantification of HIV-1-Induced Cytopathogenicity in Monocyte-Macrophages Exposed to Macrophage-Colony Stimulating Factor. J . Virol. Methods 1992, 40, 275-286.

(39) Pauwels, R.; Balzarini, J .; Baba, M. Rapid and Automated Tetrazolium Based Colorimetric Assay for the Detection of AntiHIV Compounds. J . Virol. Methods 1988, 20, 309-21.
(40) Chou, T. C. Derivation and Properties of Micaelis-Menten Type and Hill Type Equations for Reference Ligands. J . Theor. Biol. 1976, 59, 253-276.

(41) D'Atri, S.; Tentori, L.; Fuggetta, M. P.; Marini, S.; Bonmassar E. A Miniaturized Cell-mediated Cytotoxicity Assay with Human Effector Mononuclear Cells. Int. J . Tissue React. 1986, VII (5) 383-390.

(42) Chou, T. C.; Talalay, I. Quantitative Analysis of Dose-Effect Relationships: the Combined Effects of Multiple Drugs or Enzyme Inhibitors. Adv. Enzyme Regul. 1984, 22, 27-55.

J M0010365 